\title{
Ethnologies
}

Sibelan Forrester, Helena Goscilo and Martin Skoro. Baba Yaga. The Wild Witch of the East in Russian Fairy Tales. (Jackson: 2013, University of Mississippi Press. Pp. 256. ISBN: 978-1-617035-96-8)

\section{Lydia Bringerud}

Volume 35, numéro 2, 2013

URI : https://id.erudit.org/iderudit/1026556ar

DOI : https://doi.org/10.7202/1026556ar

Aller au sommaire du numéro

Éditeur(s)

Association Canadienne d'Ethnologie et de Folklore

ISSN

1481-5974 (imprimé)

1708-0401 (numérique)

Découvrir la revue

Citer ce compte rendu

Bringerud, L. (2013). Compte rendu de [Sibelan Forrester, Helena Goscilo and

Martin Skoro. Baba Yaga. The Wild Witch of the East in Russian Fairy Tales.

(Jackson: 2013, University of Mississippi Press. Pp. 256. ISBN:

978-1-617035-96-8)]. Ethnologies, 35(2), 205-207.

https://doi.org/10.7202/1026556ar d'utilisation que vous pouvez consulter en ligne. 
human differences; however, silly size-related puns and referring to Anna as "the giant" or to Anna and Martin collectively as "the giants" occasionally undermines her efforts. Giants are the fictional protagonists of legends and myths. Anna Swan was a human being suffering from a medical condition. Her story took place in the mid-nineteenth century, but we live in modern times and people-first language - putting the person before the disability - is common practice today.

Emily Urquhart

Sibelan Forrester, Helena Goscilo and Martin Skoro. Baba Yaga. The Wild Witch of the East in Russian Fairy Tales. (Jackson: 2013, University of Mississippi Press. Pp. 256. ISBN: 978-1-617035-96-8)

With more than fifty pages of introductory material, this book seeks to acquaint the reader with some context for the Baba Yaga tales before providing twenty-nine of them. Jack Zipes has written the forword, which situates Baba Yaga tales among their international neighbours. Zipes stresses Baba Yaga's pre-Christian character, pointing out that even when other monotheistic religions, such as Islam and Judaism are included in her tales, Baba Yaga opposes them all. One of Zipes's most interesting connections is with a Sicilian character who, like Baba Yaga, is likely connected to an early pagan goddess.

The rest of the book is predominantly authored by Sibelan Forrester, though Helena Goscilo and Martin Skoro are responsible for the images in the book and their explanations. In the introduction, much of Forrester's background information is linguistic, delving into how Baba Yaga might have been named, for example. He connects information about the uses of words over time with multiple uses of words in the present to suggest multi-valent readings of Baba Yaga and other characters who show up in her tales. He also notes that, since Baba Yaga is rarely capitalized in Russian, and her manifestations can be so varied, she is probably not meant to be a single person. A Baba Yaga is more likely a type of character. 
There is discussion of the objects with which Baba Yaga is associated, such as the mortar and pestle and the loom, and how these are connected with traditional women's activities in Russia. At the same time, though, Baba Yaga is larger than gender. Forrester suggests that her mortar and pestle represent both male and female, making her "contradictory and allembracing" (xxx). She is sometimes connected with Mother Earth, death and rebirth. Forrester summarizes Baba Yaga's many roles as "initiatrix, a vestigial goddess, a forest power, and a mistress of birds or animals" (xxxix).

All the tale types which Forrester has included in the book are taken from the collections of nineteenth century folklorists, most famously Nikolai Afanas'ev. The twenty-nine which Forrester has included in the volume are meant to show how varied the character of a Baba Yaga can be and how she might have functioned in the belief systems of Russian villagers even into the twentieth-century. Baba Yaga is sometimes a mother, a cannibal, a witch, a helper, or a mortal old woman - none of which are mutually exclusive. Above all, as Forrester suggests in his introduction, she teaches lessons to the young characters alongside her. He writes that Baba Yaga tests "peasant virtues: knowledge of the skills of husbandry and housekeeping, patience, persistence, kindness, generosity, and the capacity for hard work" (xxxix). Forrester also suggests that Baba Yaga is meant especially to test young women who are on the thresholds of rites of passage, like adolescence and marriage.

One of the book's greatest functions is its combination of images, provided by Goscilo and Skoro. The book successfully shows us how Baba Yaga has been imagined over time. There are early images from woodcut prints and paintings, illustrations from children's books, and more contemporary images from graphic novels like Hellboy, puppet shows, art pieces, steampunk cartoons, film covers, and even her image on a pair of Keds tennis shoes, to name only a few. These visuals complement the text nicely, helping the reader to get a sense of Baba Yaga's uses and audiences in different contexts.

In the preface, Forrester, Goscilo and Skoro say that their intended readership for the book are both academics and those outside academia. Those with backgrounds in Russian cultural studies or language may gain information about the study of folklore. Those who are folklorists will gain information about Russian culture, particularly the pre-Christian spiritual landscape and its continued influence on vernacular belief into the nineteenth century. The combination of beautiful images with stories, 
though, is appealing to any lover of folktales. The book might be most useful for students of Slavic culture and language.

Lydia Bringerud

Memorial University

Harald Welzer, Sabine Moller et Karoline Tschuggnall. "Grand-Père n'était pas un nazi ". National-socialisme et Shoah dans la mémoire familiale. (Paris, Gallimard, 2013. Pp. 344. Coll. "NRF essais". ISBN 978-2-07-013589-9)

La sortie récente de la traduction française de l'ouvrage intitulé «Grand-Père n'était pas un nazi ». National-socialisme et Shoah dans la mémoire familiale de Harald Welzer, Sabine Moller et Karoline Tschuggnall, traduit par Olivier Mannoni, a permis d'attirer l'attention sur la manière dont les différentes générations allemandes ont reçu et décanté le passé nationalsocialiste et la Shoah. L'ouvrage a paru, au départ, aux Éditions Fisher à Francfort en 2002. C'est donc avec un certain recul que nous recevons cette longue enquête-analyse réalisée en Allemagne pendant plusieurs années, qui a recueilli les témoignages de 40 familles et de 182 entrevues individuelles ou entretiens familiaux (313). Harald Welzer est psychosociologue et dirige à Essen le Centre de recherche interdisciplinaire sur la mémoire auquel collabore Sabine Moller qui est, quant à elle, à l'Université Humboldt de Berlin. Karoline Tschuggnall est membre de l'Institut de psychologie de l'Université libre de Berlin.

Autant dire que l'on décèle aisément l'axe « histoire psychologique » à la lecture de ce livre qui permet ainsi, au fil des entretiens et de leurs analyses, de comprendre que la "mémoire »du Troisième Reich est extrêmement lacunaire - voire faussée - au sein des familles. Une lacune qui semble s'intensifier au fil des générations.

Pour démontrer ce constat annoncé dès l' « avertissement aux lecteurs » (7) et pour l'illustrer, les auteurs se servent de ces dizaines d'entretiens et s'appuient sur un certain nombre de citations extraites directement 